\title{
Alanvaihto ja ammatillisen identiteetin muutos ruumiillisina tiloina ja tuntemuksina
}

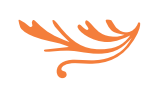

Kouluttautuminen uuteen ammattiin aikuisiällä tuo mukanaan uuden ammatillisen identiteetin. Sen omaksuminen on raskasta ja yksinäistä mutta tarjoaa mahdollisuuden tutustua itseen. Alanvaihto on kokonaisvaltainen ja ristiriitainen prosessi, joka usein yllättää alanvaihtajan itsensäkin.

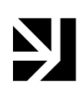

CECILIA, YKSI TUTKIMUKSENI haastateltavista, kuvailee seuraavasti tuntemuksiaan ja sitä maastoa, josta hänen alanvaihtonsa kumpusi.

"se ei käyny niinku mulle koskaan mun kohdal henkilökohtasel tasolle . muttaaa . sen kans oli jotenkin tosi vaikee elää, plus sit et he [työnantaja] olis vaatinu et se koko elämä olis pitäny niinku . fokusoida . siihen maailmaan"

\section{$[--]$}

"ja se oli myös aika pinnallinen maailma, semmonen mis tavallaan vaik mä rakastin niit kauniit materiaalei ja se oli must tosi mä sain tehdä semmost tosi luovaa työtä ja tosi itsenäisesti ja mä tiedän et mul oli tosi hyvii asiakkait jotka niinkun tykkäs ja luotti niinku minuun . ja se oli osittain tosi kivaa työtä, mul oli tosi kivat alaiset ja mutta . mut niinku sil tapaa tuntu väärältä”

Cecilia toimi myymäläpäällikkönä sisustusalan liikkeessä, ja kuten lainaus osoittaa, hänellä olisi ollut monta hyvää syytä jäädä. Työn tekemisen olot kuitenkin tuntuivat vääriltä, ja niiden kanssa oli vaikea elää, mikä sysäsi hänet muutokseen. Uusi ura löytyi erityispedagogiikasta - ristiriitaisten tuntemusten ja vaiheiden kautta.

Tarkastelen artikkelissani monitieteisesti keskiikää lähestyvien naisten omaehtoista kouluttautumista uudelle alalle. Kysyn, miltä kokonaisvaltaisesti 
Ammatillisen identiteetin

RAKENTAMINEN ON

\author{
RUUMIILLISTA KUTEN TYÖ \\ YLIP $\ddot{A} \ddot{A} T \ddot{A} \ddot{A}$.
}

ajateltuna tuntuu vaihtaa alaa. Keskiössä ovat ruumiilliset tuntemukset, tilat ja tunnesävyt ammatillisen identiteetin muuttuessa joksikin aivan toiseksi. 'Ruumiilla' tarkoitan samaa kuin keho, kokonaisuutta, jona elämme ja olemme (Grosz 1994; MerleauPonty 2012).

Suomen itsenäisyyden juhlarahaston (Sitra 2017) tutkimuksen mukaan jopa kuusi kymmenestä työikäisestä on vaihtanut ammattia tai alaa työuransa aikana. Heistä noin joka toinen oli opiskellut uuden ammatin tai tutkinnon (Sitra 2017). Alanvaihto koskettaa ja liikuttaa siten monia aikuisia. Osana oman elämän "rakentamista" se on samalla nykykulttuurille leimallinen ilmiö (Laakkonen 2015; LaPointe \& Heilmann 2014), jonka aikuiskasvatuksellista puolta on ajankohtaista tarkastella.

Alanvaihdot voivat olla eriasteisia ja tapahtua eri syistä, oma-aloitteisesti tai pakotetusti (Koivunen, Lämsä \& Heikkinen 2012; Louis 1980). Tarkastelen ihmisen oma-aloitteista siirtymistä kokonaan toiselle ammattialalle. Alanvaihtoa ja ammatinvaihtoa pidän toistensa synonyymeinä. Puhun kuitenkin alanvaihdosta, sillä se kattaa nekin, jotka opiskelevat sellaista alaa, joka ei valmista mihinkään tiettyyn ammattiin.

Viimeaikaisessa alanvaihtotutkimuksessa on korostettu identiteetin muuttumisen merkitystä alanvaihdossa (Ibarra 1999, 2004; Khapova, Wilderom \& Svensson 2007). Artikkelillani vien keskustelua aikuisen identiteetistä ammattilaisena ja oppijana (Eteläpelto \& Vähäsantanen 2010; Filander 2006; LaPointe 2011; Leivo 2010) aiempaa ruumiillisemmalle tasolle (Onnismaa \& Pasanen 2015; Räsänen \& Trux 2012; Satama 2017). Alanvaihtoon kuuluu kokonaisvaltaista identiteetin työstämistä, jota ihminen tekee koko ruumiillaan.

Ammatillisen identiteetin rakentaminen on siis ruumiillista, mutta niin on työ ylipäätään. Työn tarkasteleminen ruumiillisesta näkökulmasta on lisääntynyt. Esillä ovat olleet sukupuoli ja muut yhteiskunnalliset erot (Huopalainen \& Satama 2018; Johansson, Tienari \& Valtonen 2017; Parviainen, Kinnunen \& Kortelainen 2016; Rikala 2013; Valkonen \& Valkonen 2014) sekä työntekijä osana työorganisaatioita (Laulainen \& Hujala 2016; Satama 2017; Strati \& deMontoux 2002; Vacchani 2006).

Opettajuustutkimuksessa ja kasvatustieteellisessä työn ja työelämän tutkimuksessa keskustelu ruumiillisuudesta on toistaiseksi ollut hajanaista ( $\mathrm{mm}$. Aromaa 2014; Estola \& Elbaz-Luwisch 2017; Gordon, Holland \& Lahelma 2000; Kinnunen \& Seppänen 2012; Kamila 2012; Nikkola \& Harni; 2015; Mäkikoskela 2007; Saari 2016). Ruumiillisuuden tutkimuksessa tieteiden väliset rajat kuitenkin hämärtyvät, sillä ruumis on aidosti monitieteinen tutkimuskohde.

Ruumiillisuuden näkökulmaa voidaan aikuiskasvatustieteellisessä tutkimuksessa hyödyntää monella eri tavalla. Tämä artikkeli keskittyy kuitenkin affekteihin, jotka merkitsevät kokonaisvaltaisia ruumiillisia tuntemuksia (Jokinen, Venäläinen \& Vähämäki 2015, 18-21). Tutkijat puhuvatkin affektiivisesta käänteestä tai käänteistä, joiden myötä monella alalla on alettu kiinnittää huomiota tunteisiin ja tuntemuksiin (Jokinen ym. 2015; Koivunen 2010). Enää tuntemusten yhteiskunnallista merkitystä ei ole tarvetta väheksyä tai piilotella yksityisen elämänpiirin puolelle. Affektiivisuuden ymmärränkin tarkoittavan tunnepitoista, tuntemukset huomioivaa lähestymistapaa.

Työelämää ja sitä koskevia keskusteluja ovat perinteisesti leimanneet tietynlainen rationaalisuus ja kontrolli (Julkunen 2008). Affektit ovat kuitenkin aina olleet olemassa työkulttuureissa (Mannevuo 2015), ja ruumiista on tullut yhä ajankohtaisempi, kun ihmisen kaikki kyvyt valjastetaan taloudellisen hyödyntämisen välineiksi (Brunila, Onnismaa \& Pasanen 2015, 9; Ylitapio-Mäntylä 2016). Tuntemukset syntyvät identiteettineuvotteluissa, joita käydään vuorovaikutuksessa muiden ihmisten ja ei-ruumiillisten toimijoiden, kuten esineiden ja fyysisten tilojen, kanssa (Laulainen \& Hujala 2016). Ne ovat aina yhteydessä yhteiskunnallisiin odotuksiin (Mannevuo 2015). 


\section{Alanvaihdot ja SiIRTymät}

URALLA OVAT ENENEVÄSS̈̈

M $\ddot{A} \ddot{R I N ~ E N N U S T A M A T T O M I A . ~}$

Työelämään liitetty kontrolli (Julkunen 2008) koskee myös käsityksiä työntekijöistä. Heidän on oletettu käyttäytyvän rationaalisesti ja tavoittelevan yhä parempaa asemaa hierarkiassa (Ekonen 2007). Niinpä urankin on ajateltu kehittyvän ennakoitavien vaiheiden mukaan (Ekonen 2007, 22-23) ja alan vaihtamisen perustuvan tietoon itsestä ja omista piirteistä, vaikka olennaisempaa on ymmärtää muuttuvaa ja muokattavissa olevaa ammatillista identiteettiä (Ibarra 2004).

Alanvaihdot ja muut siirtymät uralla ovat enenevässä määrin ennustamattomia, eikä niihin liity selkeitä sääntöjä, joiden mukaan toimia (LaPointe 2011, 20). Siksi ei riitä, että identiteettejä tarkasteltaisiin pelkästään perinteisissä siirtymäriiteissä, kuten työhön sosiaalistumisessa, ylennyksissä tai eläköitymisissä (LaPointe 2011, 20). Alanvaihtoon kuuluvan identiteettityön ymmärtäminen kaipaa nykyistä kokonaisvaltaisempaa näkökulmaa.

\section{ALANVAIHDON RUUMIILLISUUS JA AFFEKTIIVISUUS}

Työn on katsottu muuttuneen yhä yksilöllistyneemmäksi ja kiinnittyvän aiempaa enemmän työntekijän persoonaan. Taustalla ovat lisääntynyt individualismi ja markkinamuotoisuus (Julkunen 2008, 122). Kollektiiviset luokka- ja ammatti-identiteetit ovat heikentyneet ja luoneet painetta henkilökohtaiselle identiteettityölle. Työtä ei enää voi vain mekaanisesti suorittaa, vaan työntekijän tunteet, aistit ja koko elämä vedetään mukaan (Onnismaa \& Pasanen 2015, 263).

Tunteita ilmennetään ruumiillisesti. Tunteet sekä tuntuvat että näkyvät ulospäin ruumiissamme. Vuorovaikutuskin vaatii ruumiillisia eleitä. Toisaalta ruumiillisuus ei kuitenkaan palaudu pelkästään fysiologisiin, biologisiin, hormonaalisiin tai materiaalisiin mekanismeihin, vaan se sisältää samalla yksilön elämää, kokemuksia, persoonaa, kollektiivista toimintaa ja valtaa koskevia piirteitä sekä kulttuurisia tapoja. (Parviainen ym. 2016, 9-10,19.)

Ruumiin voi ajatella olevan sellainen objekti, joka sisältää sisäpuolen ja elää sen mukana, ja jolla on kyky pitää itseään ja muita subjekteina (Grosz 1994). Kaikki ruumiilliset toiminnot osallistuvat havaitsemiseen, minkä vuoksi ruumis on paljon muutakin kuin väline tai keino: "[--] se on ilmaisu itsestämme maailmassa, pyrkimystemme näkyvä muoto". (MerleauPonty 2012, 63-64.)

Ruumis asettaa viime kädessä rajat yksilön toiminnalle ja muutokselle. Muuttuminen työelämän kontekstissa tarkoittaa aina oppimista, kulttuurin sisäistämistä, asiantuntijaksi kasvamista ja identifikaatiota (Räsänen \& Trux 2012,246). Tämä muutos ei onnistu älyllisellä päättelyllä, vaan se on jotain paljon kokonaisvaltaisempaa (Räsänen \& Trux 2012, 246). Yhä tehostetummassa työssä työntekijä voi helpostikin törmätä ruumiillisiin rajoihinsa. Turhautuminen liian vähäisiin haasteisiin tuntuu sekin ruumiissa. Ruumis myös vanhenee. Näillä kaikilla tavoin ruumiillisuus voi toimia alanvaihtoajatusten herättäjänä ja ammatillisen identiteetin muokkaajana. Lisäksi yhdenlainen kehitys sulkee pois monia muita (Wolkowitz 2006). Jos ihminen toiminnallaan muokkaa itsestään uudenlaisen, vanha muoto häviää (Lahikainen \& Harni 2016,35-36).

Affektiivinen käänne on ollut havaittavissa usealla tieteenalalla 2000-luvulla. Se kritisoi pitkään jatkunutta kielellistä käännettä ja konstruktionistisia käsityksiä siitä, että ne helposti hukkaavat tunteet ja tunteellisuuden (Jokinen ym. 2015, 8-9). Affektien tutkimisesta on yhtäältä haettu vastauksia yksilön yhä syvällisempään ymmärtämiseen ja toisaalta keinoja ylittää yksilö ja löytää jotakin yhteistä (Koivunen 2010, 9). Työelämän rationaalisuuden ja ihmisen tunteellisuuden välinen ristiriita kaipaakin lisää tutkimusta ja uusia jäsennyksiä. Affektien tarkasteleminen auttaa kyseenalaistamaan ihmisen sellaisia puolia, joita ei voida ymmärtää ainoastaan kognitiivisesti tai rationaalisesti sekä tunnistamaan sellaisia yhteiskunnallisen uusintamisen ja muutoksen muotoja, jotka 
Emootioita Ja AFFEKTEja

EI OLE SYYTÄ ASETTAA

VASTAKKAIN.

muuten jäisivät huomiotta (Jokinen ym. 2015; Koivunen 2010).

Tunne eli emootio on perinteisesti liitetty mieleen, mutta affekti viittaa koko ruumiiseen (Jokinen ym. 2015, 18-21). Sen ajatellaan olevan jonkinlaista potentiaalia, joka ei palaudu yksilöön ja jota ei pystytä kovin hyvin empiristisesti tarkastelemaan. Emootiot ovat kognitiivisesti tunnistettavia, kielellisesti nimettyjä ja kulttuurisesti tunnistettuja tuntemuksia. Niistä voi puhua ja niitä voi vaikkapa teeskennellä. Affektit ovat jotain emootioita avoimempaa; niihin liittyvää mutta niihin palautumatonta. Ne osoittavat kielellisen ja rationaalisen selittämisen ohi tai yli ja korostavat kokemuksellisuutta. (Jokinen ym. 2015, 18-21; Koivunen 2010, 9; Mannevuo 2015; Wetherell 2012.) Affektiteoreetikko Brian Massumi (2002) käsittää affektit autonomisina, ainakin jossain määrin riippumattomina sosiokulttuurisista merkityksenannoista. Hänen mukaansa emootiot ovat ikään kuin ihmisen ominaisuuksia tai omaisuutta, mutta affekti läpäisee ja valtaa ihmisen yllättäen, hetkellisesti ja ilman valmista tulkintakehystä tai reaktiotapaa (Massumi 2002).

Emootioista ja affekteista on keskusteltu eri tieteenaloilla ja erilaisista teoreettisista lähtökohdista (Salmela 2017). Niitä ei kuitenkaan ole syytä asettaa vastakkain. Affektitutkijoiden Eeva Jokisen, Juhana Venäläisen ja Jussi Vähämäen (2015) tapaan näen hyödyllisenä tarkastella niitä pieniä siirtymiä ja mekanismeja, joissa epämääräiset tunnut ja tunnevirrat alkavat saada muotoja. Niissä affektit luovat mahdollisuuksia tunnistettaville emootiolle, vaikka eivät täysin tyhjene tai palaudu niihin (Jokinen ym. 2015, 24). Toisille tutkijoille affektit eivät edusta esisosiaalista, vaan niitä käytetään teoretisoimaan sosiaalista (Koivunen 2010, 18). Näin päästään liikkumaan suljetuista järjestelmistä kohti avoimia esimerkiksi ottamalla huomioon sellaiset voimat, joita eletty ruumis ei koskaan voi kokea, kuten kosmologiset, ulkopuoliset voimat (Koivunen 2010, 18).

Affektiteoreettiseen otteeseen nojaava tutkimus on kiinnostunut tuntemuksista laajassa mielessä: ei ainoastaan sellaisista tunteista, joilla on nimi vaan myös muunlaisista tunnuista: mielikuvista, olotiloista, aistinvaraisista vivahteista, tai kuten filosofi Paolo Virno (2006) luonnehtii, tunnesävyistä. Tavoite on myös löytää niistä jotakin yleispätevää, jonka avulla ymmärtää tässä tapauksessa alanvaihtoa ja ammatillisen identiteetin muutosta - ei pelkästään reaktioina yhteiskunnan tai talouden muutoksiin vaan jonain uutena ja orastavana - jonain, mille ei ole vielä nimeä (ks. Jokinen ym. 2015, 10).

Jos taas tarkastellaan ruumiillisuutta ja affekteja suhteessa ihmisen ammatilliseen identiteettiin ja erityisesti sen muuttumiseen, huomataan, kuinka nämä ovat kietoutuneita toisiinsa. Sukupuolen ja ammatillisuuden suhdetta tutkinut Kathryn Haynes (2012) esittää käytettäväksi käsitettä 'ammatillinen ruumiillinen identiteetti'. Fyysinen ruumis on tärkeä osa ammatillisuutta, sillä se symboloi identiteettiä ja on siis tosiasiassa identiteetin ruumiillistuma (Haynes 2012, 504). Työelämässä ruumis toimii välineenä mukautua tai olla mukautumatta sosiaalisiin normeihin (Haynes 2008). Organisatoriset ja ammatilliset ruumiillisuudet saattavat törmätä yhteen muiden ruumiillisuuksien, kuten raskauden tai lapsen saamisen, kanssa ja vaikuttaa ruumiillisiin ja affektiivisiin käytänteisiin, tuntemuksiin ja identiteetteihin (Haynes 2008). Muuttuva identiteetti taas raivaa tilaa itselleen ruumiillisesti ottamalla haltuun uusia käytänteitä, kuten vuorovaikutustyyliä, pukeutumistapaa tai päivittäisiä rutiineja.

Näen ammatillisen identiteetin tutkimuksessani kerronnallisesti rakentuneena, omaa työtä ja ammatillisuutta koskevana ruumiillisena, dynaamisena prosessina, joka muovautuu henkilökohtaisen ja sosiaalisen välimaastossa ja sisältää sekä pysyviä että muuttuvia ulottuvuuksia (Beauchamp \& Thomas 2009; Eteläpelto \& Vähäsantanen 2010; Hänninen 2002; Izadinia 2013).

Identiteetit tulevat näkyviksi silloin, kun niihin liittyy paineita ja ristiriitoja (Eteläpelto \& Vähäsantanen 2010), kuten alanvaihtotilanteissa usein voi olla. 
HaAstatteluissa

\section{OTETTIIN TILAA OMAN}

\section{TOIMINNAN TARKASTELULLE JA TUNTEMUSTEN}

\section{MUISTELEMISELLE YHDESS $\ddot{A}$}

TUTKIJAN KANSSA.

Tuntemukset ja ruumiillisuus ovat olennainen ja luonnollinen osa ammatillista identiteettiä (Alsup 2006), mutta tätä puolta ei ammatillisten identiteettien tutkimuksessa ole tehty kovinkaan näkyväksi eikä ruumiillisuutta ole kytketty ammatillisten identiteettien muuttumiseen.

\section{TUTKIMUSKYSYMYS, AINEISTO JA METODI}

Tutkimuskysymykseni on, miltä alanvaihto kokonaisvaltaisesti tuntuu. Se jakautuu alakysymyksiin:

1. Miltä tuntuu irrota aiemmasta ammatillisesta identiteetistä?

2. Miltä tuntuu olla kahden ammatillisen identiteetin välissä?

3. Mitä muita tuntemuksia alanvaihtoon liittyy?

4. Miltä tuntuu kasvaa uuteen ammatilliseen identiteettiin?

Keskityn korkeakoulutettujen ja ennen alanvaihtoa uraansa rakentaneiden ihmisten tuntemuksiin. Samaten olen kiinnostunut ihmisistä, jotka suorittivat akateemista tutkintoa, sillä yliopisto-opinnoissa välitetään tietojen tai taitojen lisäksi asenteita ja ammatillista identiteettiä (Nori \& Mäkinen-Streng 2017, 339).

Alanvaihtajan koulutustaustalla on merkitystä. Suomen Ammattiliittojen Keskusjärjestö SAK teetti tutkimuksen, jossa selvitettiin työntekijäammatista toiseen työntekijäammattiin siirtyneitä. Sen mukaan uusi ammatti-identiteetti oli löytynyt helposti, ja entisen ammatin osaamisalueita käytettiin hyväksi uudessa tilanteessa (Vahtera 2017).

Tutkimukseeni osallistui kolme 35-45-vuotiasta naispuolista opettajaopiskelijaa. Käytän heistä peite- nimiä, ja lisäksi muitakin tietoja on muutettu haastateltavien anonymiteetin säilyttämiseksi. Aineistosta ilmeni, että jokaisella heistä oli ollut selvä aikaisempi ammatillinen identiteetti, joka oli alkanut murtua ja muuttua. Annalla se oli liiketoiminnan konsulttina, Birgitalla kirjastonhoitajana ja Cecilialla sisustusalan myymäläpäällikkönä. Kaikilla oli myös aiempi korkeakoulututkinto.

Kokosin tutkimusaineiston haastattelemalla edellä mainittuja. Haastattelut kestivät reilusta tunnista kolmeen tuntiin ja niistä kertyi yhteensä 84 litteroitua sivua. Kolme haastattelua tarjosivat tutkimuskysymysten kannalta runsaasti olennaista aineistoa.

Haastatteluaineistoon perustuvassa tutkimuksessa on syytä kysyä, missä märin ihmistieteellisen tutkimuksen keinoin on mahdollista päästä käsiksi ruumillisuuteen. Mikä on ruumiin suhde tekstiin, puheeseen ja kieleen (Jokinen, Kaskisaari \& Husso 2004, 11)? Filosofi Margaret Wetherell (2012) puhuu affektiivis-diskursiivisesta merkityksen muodostumisesta. Hänen mukaansa käyttökelpoisin tapa tehdä affektitutkimusta on tarkastella affekteja suhteessa tilanteisiin ja sosiaalisiin käytäntöihin. Affektit eivät ilmene sosiaalisessa tyhjiössä vaan osana sosiaalista vuorovaikutusta. (Kolehmainen 2014, 185; Wetherell 2012.) Niinpä kuten affekteja ja emootioita, myöskään affekteja ja kieltä ei tule asettaa vastakkain, vaan ne voidaan nähdä dialektisessa suhteessa toisiinsa.

Pyysin haastateltavia vapaasti kertomaan alanvaihtotarinansa. Pyyntö toi esille rikkaan kirjon tuntemuksia ja antoi haastateltaville mahdollisuuden nostaa esille alanvaihtotarinastaan juuri niitä kohtia, joita he itse halusivat. Haastattelujen toteuttaminen nimenomaan elämäkertahaastatteluina (Estola, Uitto \& Syrjälä 2017, 156) antoi mahdollisuuden alanvaihdon odotusten haastatteluun. Lisäksi kutsun haastatteluja refleksiivisiksi, sillä niissä otettiin tilaa oman toiminnan tarkastelulle, tuntemusten muistelemiselle ja pohdinnalle yhdessä toisen osapuolen eli tutkijan kanssa (Högbacka \& Aaltonen $2015,10-11)$. Haastattelut olivat samalla sisäpiirihaastatteluja (Juvonen 2017), sillä olen itse korkeakoulutettu alanvaihtaja. 
Analyysin ensivaiheessa paikansin niitä tekstin osia, joissa haastateltavat puhuivat ruumiillisuudesta (Estola \& Elbaz-Luwisch 2010, 702). Tuolloin he 1) puhuivat väljästi ottaen jonkinlaisista tuntemuksista (Jokinen ym. 2015), 2) vaikuttivat tekevän identiteettityötä vuorovaikutuksessa muiden ihmisten kanssa (LaPointe 2011), 3) vaikuttivat tekevän identiteettityötä suhteessa ei-ruumiillisiin toimijoihin (Laulainen \& Hujala 2016) tai 4) kuvailivat aistinvaraisia asioita tai käyttivät mielikuvitusta tai mielikuvia (Satama 2017). Tarkastelemalla tuntemusja aistimuspuheen lisäksi identiteettityön tekemistä ympäristön kanssa tuntemukset näyttäytyivät osana sosiaalisia käytänteitä.

Sitten tarkastelin aineistoa kerronnallisesta näkökulmasta. Kerronnallisuus on yksi vakiintuneita tapoja ymmärtää identiteettejä (Beauchamp \& Thomas 2009; Hänninen 2002). Hyödynsin odotusanalyysiä, joka on saanut alkunsa kielitieteilijä Deborah Tannenin (1993) määrittelemistä odotuksen osoittimista ja jota on Suomessa kehitetty edelleen (Hyvärinen 2010). Odotusanalyysi perustuu ajatukseen, että kerrottavuuden perusehto on jokin yllättävä poikkeaminen oletetusta tapahtumakulusta (Hyvärinen 2010). Kertomus ammatillisen identiteetin muuttumisesta voi olla erityisen tiheä odotusten kannalta ja näin ollen paljastaa mielenkiintoisia seikkoja sosiaalisista odotuksista. Kertomuksia voidaankin pitää kommentteina tavanmukaiseen ja odotettuun tapahtumakulkuun.

Odotusanalyysissä pyritään paikantamaan erilaisten odotusten osoittimien perusteella kohtia, joissa kertoja neuvottelee kerrottujen tapahtumien ja kyseisiä tapahtumia koskevien kulttuuristen odotusten välillä (Hyvärinen 2010, 111-112; Rikala 2013, 65). Odotuksen osoittimia, kielellisiä merkkejä, voivat olla esimerkiksi toisto, korjaus, paluu kronologiassa, varaukselliset ilmaisut, kieltomuodot ja arvioiva kieli (Tannen 1993, 41-51). Hyödynsin odotusanalyysiä soveltuvin osin sen perusteella, mitä odotuksen osoittimia aineistosta löytyi, sillä joitakin odotuksen osoittimia ilmeni enemmän ja toisia vähemmän. Kohdistin odotusanalyysin erityisesti niihin tekstin osiin, joissa haastateltavat puhuivat ruumillisuudestaan käyttäen odotuksen osoittimia.
Yleisesti ottaen haastattelut olivat eräänlaisia kasvutarinoita. Ne olivat kertomuksia "oman jutun" etsimisestä ja löytämisestä, oikeastaan itsensä löytämisestä. Kaikissa kertomuksissa oli tosin kärsimystä ja vaikeuksia, mikä oli sidoksissa luopumisen tuskaan vanhasta alasta, välitilan epämääräisyyden tuntemuksiin ja edelleen kalvavaan, uuden ja vanhan 'maailman' väliseen ristiriitaan. Alanvaihtajan tuntemukset jäsentyvät ruumiillisiksi tiloiksi: irtoamiseksi, puhdistumiseksi, tunnustelemiseksi ja tulollaan olemiseksi.

\section{IRTOAMINEN}

Millaiset olotilat käynnistivät haastateltavien alanvaihtoprosessin? Mitkä olivat niitä hetkiä, jolloin he irrottautuivat tai irtosivat aikaisemmasta ammatillisesta identiteetistään? Haastateltavien kertomuksissa oli kohtia, joissa he kuvasivat nähneensä työnsä uudessa valossa. Ne ovat voimakkaita ja kokonaisvaltaisia reflektion paikkoja, joissa oma työ ja sitä koskevat rutiinit ja merkitykset näyttäytyvät toisenlaisina (Kontinen, Houni, Karsten \& Toivanen 2013, 255).

Cecilia kertoi tuntemuksistaan uuden sisustusmyymälän avajaisissa:

"joo kyl mä muistan et kun esimerkiks mmm . kun oli uuden myymälän avajaiset ja . sitten ni tota meidän piti olla siel tavallaan niinku sitä asiakasiltaa pitämässä ja tota . se oli semmonen niinku näytelmä .aina . jotenki et kaadetaan kuohuviiniä ja on hienon näköstä ja sit puhutaan et 'ai että!' ku joku ja mä tulin kotii sielt ja . mul oli ihan tosi semmonen niinku likanen olo et semmonen et mä istuin niinku ja tuijotin ikkunast ulos . ulos et mul oli ihan semmonen et hyi et mä en oo niinku tommonen . niinku et tää on tosi ällöttävää (naurua) ja sit jotenki siit mul tuli tosi voimakkaasti semmonen et mä en halua niinku tätä”

Cecilia vertaa tilannetta näytelmään. 'Näytelmä' metaforana viittaa johonkin ei-aitoon, tekemällä tehtyyn. Kuohuviini ja hieno ympäristö ovat identiteettityön ei-ruumiillisia toimijoita, jotka Cecilian tilanteessa alleviivaavat hänelle tilanteen epäautenttisuutta. Ensin Cecilian puhe on imperfektissä, mutta kuohuviinin kohdalla hän vaihtaa preesensiin ikään 


\section{RuUMis VIESTITT $\ddot{A} \ddot{A}$}

\section{TUNTEMUSTEMME JA \\ OLOTILOJEMME KAUTTA}

ASENTEISTAMME.

kuin alleviivatakseen tilanteen absurdiutta. Sitten Cecilia vaihtaa takaisin imperfektiin ja kuvailee olotilaansa adjektiivilla likainen, joka on voimakas ilmaus. Hän ei koe oloaan puhtaaksi ja seesteiseksi, vaan hän on tahraantunut, tai hänet on tahrattu.

Sitten Cecilian kerronnassa tapahtuu identiteettityön kannalta ratkaiseva vertaaminen, minkä hän toteaa painokkaasti: "mä en oo niinku tommonen". Hän ei halua identifioitua työpaikkansa ihmisiin eikä olla sellainen kuin tilaisuudessa pitäisi olla. Kuvatessaan tilanteen "tosi ällöttäväksi", Cecilia on jo irronnut aikaisemmasta ammatillisesta identiteetistään. Hän kertoo painokkaasti, kieltomuotoa käyttäen, tehneensä itselleen selväksi, ettei halua tätä.

Birgitta oli kokenut irtoamisen ja oman työnsä toisin katsomisen hiljalleen:

"ku se on ollu mulle hirveen vaikee prosessi sen takia koska mä aattelin et kun mä sinne menin ni et waaau nyt mä oon löytäny sen mun alan”

$[--]$

"ja jotenki tietysti se semmonen niinku kasvaminen siitä pois"

$[--]$

"et mä oon kokenu jo vuosia et mä oon tavallaan niinku opettaja et mä oon oikea ihminen väärässä paikassa, väärässä työssä”

Birgitta käyttää ilmaisua "kasvaa pois", mikä on mielenkiintoinen aikuisopiskelijan ammatillisen identiteetin kehittymisen kannalta. Samalla kun opintojen myötä kasvetaan uuteen identiteettiin, kasvetaan pois jostakin. Birgitan tuntemus siitä, että hän on identiteetiltään opettaja, vaikka työskentelee kirjastonhoitajana, kertoo hiljalleen tapahtuneesta irtoamisesta ja irrallaan olemisesta. Hän on jatkanut työssä, mutta tuntemusten tasolla hän on jokin toinen, opettaja.

Ruumis viestittää tuntemustemme ja olotilojemme kautta asenteistamme ja viime kädessä paljastaa ne. Ihminen voi jonkin aikaa teeskennellä ja pakottaa itsensä epämukaviin ja epäsopiviin työasentoihin, mutta pitkällä tähtäimellä edessä voivat olla jopa työuupumus ja masennus: ruumis sanoutuu irti yhteistyöstä (Rikala 2013). Huono olo irrottaa ihmisen ammatillisesta identiteetistään. Tämä pätee varsinkin oma-aloitteiseen alanvaihtoon. Omaaloitteisuus tai peräti vapaaehtoisuus kuulostaa kovin myönteiseltä, mutta haastateltavieni kertomukset kertovat toista. Irtoaminen on epämiellyttävää eikä ihmisen kontrolloitavissa.

\section{PUHDISTUMINEN}

Irtoamisen jälkeen haastateltavat ajautuivat pikku hiljaa, kukin omalla tavallaan välitilaan, jossa he eivät olleet enää niin sitoutuneita työhönsä, pohtivat vaihtoehtoja ja alkoivat nähdä ammatillisen identiteettinsä uudessa valossa. Ymmärrän tämän eräänlaisena puhdistumisen tilana, mikä tekee ihmisestä vastaanottavaisemman uusille kiinnikkeille. Sen paremmin puhdistuminen kuin irtoaminenkaan eivät tunnu miellyttävältä, vaan kumpaankin sisältyy perustavia epävarmuuden, epäselvyyden ja arvottomuuden tuntemuksia.

Tällaisesta välitilasta on työelämän tutkimuksessa alettu käyttää liminaalitilan käsitettä, joka on alun perin peräisin antropologiasta. Työn ja johtamisen muutoksia tutkinut Tiina Kontinen tutkijakumppaneineen (2013) esittää, että liminaalitila leimaa koko nykyistä työelämää. Se on kynnyksellä olemista, mikä voi näyttäytyä kaaoksena mutta myös uutta luovana tilana (Beech 2011; Kontinen ym. 2013).

Selkeimmin liminaalitilasta puhui Anna, joka kuvasi olotilaansa vellovaksi ja irtonaiseksi. Anna yritti väkisin saada elämänmuutoksensa, kuten hän sitä kutsui, tehtyä vuodessa. Tila oli niin epämukava, ettei hän halunnut olla siinä pidempään.

"mul oli semmonen olo, et mun pitää niinku- et tää on se mun vuos, se yks vuos, jonka aikana mä niinku . teen tän muutoksen 
//Okei, sä annoit ittelles tommosen niinko aika perspektiivin?//"

"joo . no ehkä siin oli se et koska mä aat- mun on pakko sit olla sen jälkeen niinku jossain . mä en voi olla sellases irrallises tilassa mis mä olin sen . vaikka mä koko ajan tein, mul oli se kuvio mihin mä tähtään ni . samaan aikaan kumminki oli niinku samal se . niinku vellova . epätietoisuus siitä tulevaisuudesta ja niinku se niinku ku sä et oo missään sidoksissa kun sä et oo niinku enää vanhaan työpaikkaan niinku palkkalistoilla ja niinku sielä ja sul ei oo viel opiskelija et jollain taval ei kuulu oikeen mihinkään et o vaan et sä teet niinku itsenäisesti et jollain taval must se semmonen aika . vähä niinku turvaton olo et ihminen kaipaa sitä et kuuluu johonkin . jollain tavalla . ni tota mä luulen et olis semmosta et entäs jos mä irtaudun liikaa täst vanhasta”

Lainauksessa Anna vahvistaa ja selittää välitilan tuntua useaan otteeseen. Välillä hän myös vaihtaa kerrontansa preesensiin: "mun on pakko olla sen jälkeen jossain”, mikä tihentää ja korostaa kerrontaa. Anna myös etäännyttää itsensä vaihtamalla niin sanottuun sä-passiiviin ja luettelee, mitä kaikkea välitilassa oleva ihminen ei ole. Sitten hän arvioi ja kuvailee omaa olotilaansa turvattomaksi. Lopuksi hän palaa vahvistamaan, miten asia on yleisesti ottaen: ihminen kaipaa sitä, että kuuluu johonkin.

Johonkin kuuluminen ja sidoksissa oleminen on ruumiillinen asia. Ruumiidemme kautta olemme vuorovaikutuksessa toisten kanssa, ja kun nämä siteet löystyvät, olo voi tuntua turvattomalta ja irralliselta. Lainauksen lopun potentiaalinen tapahtumienkulku kiteyttää sanoman: on täysin mahdollista, että kuuntelemalla omia ammatillisia mielenkiintojani ajankin itseni liiaksi irralleen vanhasta, tutusta ja turvallisesta työyhteisöstä.

Birgitta kertoo, kuinka epäselvältä tuntuvaa alanvaihtoa tekisi mieli jouduttaa:

"vitsi kun tää oliskin valmis et kunpa tää oliskin tässä tää homma . mut sit taas toisin perin ymmärtää et se ei oo mahollista”
Ihminen, joka on enemmän tai vähemmän systemaattisesti rakentanut uraansa ja aikaisempaa ammatillista identiteettiään, on uudessa tilanteessa, kun omaa ammatillista kasvuaan ei pystykään ennustamaan. Liminaalitila sisältää paljon potentiaalia: mikä tahansa on mahdollista - hyvässä ja pahassa (Kontinen ym. 2013, 252-255).

\section{TUNNUSTELEMINEN}

Alaa vaihtava ihminen kokeilee uudenlaisia identiteettejä niin mielikuvissaan kuin konkreettisestikin (Ibarra 1999). Opettajaksi aikova havainnoi sijaisuuksia tehdessään muita opettajia kokonaisvaltaisesti: hän esimerkiksi kiinnittää huomiota heidän pukeutumiseensa ja muuttaa omaa pukeutumistaan uuteen työympäristöön sopivaksi. Anna kuvaa pohdintaansa:

"sillon ko mä menin tekemään sijaisuuksia ni sijaisuudet sillon mä mietin sitä pukeutumista sillon niinku välitilassa”

\section{$[--]$}

"ni sillon mä mietin et apua et pukeuduks mä niinku vanhaan työpaikkaan vai pukeuduks mä miten . et mul oli siin niinku vähän semmost- hakuvaihe et mä katoin et miten opettajat pukeutuu et okei" "no aika siististi neki pukeutuu et niinku tyylikkäästi siis niinku sillee että ei ne ihan niinku mis tahansa vaatteis ollu ne opettajat sielä ett mut et jollain tavalla oli semmonen tietyl tavalla niinku rento mut jollain tavalla niinku siisti pukeutuminen . et astetta epämuk- epävirallisempi kun mitä . mitä konsulttina . et kumminki sitte oli enemmän niinku semmosta jotain semmosta niinku . no . neulepaitaakin mut kumminki enemmän jotain semmosii . vähän siistimpiä . vaatteita”

Lainauksessa on läsnä identiteettityön vuorovaikutteisuus: uutta identiteettiä rakennetaan havainnoimalla muita kyseistä työtä jo tekeviä ja pohtimalla, miltä itse näyttäisi siinä ammatissa ja miltä se tuntuisi. Identiteettiä työstetään myös vertailemalla uutta ja vanhaa keskenään. Anna kuvaa tilannetta hakuvaiheeksi. Hän ei ollut tyytyväinen konsulttimaailman 
LEIKINOMAISEN KOKEILEMISEN

\section{LISÄKSI TUNNUSTELEMINEN ON}

\section{HAPAROINTIA.}

jakkupukutyyliin eikä kokenut sitä enää omakseen. Samalla hän pelkäsi, muuttuuko pukeutuminen ja samalla identiteetti liikaa, kunnes huomasi, että opettajatkin pukeutuvat kohtalaisen siististi.

Vaatteet voidaan nähdä ei-ruumiillisina toimijoina (ks. Kamila 2012; Laulainen \& Hujala 2016), jotka vaikuttavat alanvaihtajan identiteettityöhön ja käytänteisiin, tai pikemminkin herkässä tilassa oleva ihminen antaa vaatteille merkityksiä käyttämällä mielikuvitustaan. Haastateltavat eivät kopioineet pukeutumistyyliä suoraan uusilta työtovereilta, vaan ottivat heidän pukeutumisestaan vaikutteita ja punnitsivat, sopisiko jokin vaatekappale itselle, miksi se sopisi tai ei sopisi, mitä tuntemuksia se aiheuttaisi itsessä ja minkä vaikutelman se antaisi muille.

Leikinomaisen kokeilemisen, roolileikin lisäksi tunnusteleminen on haparointia. Anna kuvaa monin kieltosanoin, miten hän piti alanvaihtoajatuksistaan työpaikalla matalaa profiilia, vaikka oli ottanut vastaan irtisanomispaketin:

"työkavereille ei, oikeestaan niille mä- valtaosalle mä en kertonu tästä mun opettajasuunnitelmasta sen enempää itse asiassa siinä vaiheessa en kertonu . et mä pidin sen suhteen työpaikal aika matalaa profiilii siitä että . et että en kertonu avoimesti ollenkaan et päinvastoin . et sit vasta sit mä jollekin sanoin et mä ehkä opiskelen et mua kiinnostaa opiskella kasvatustieteitä”

\section{$[--]$}

"mut en sen enempää . ja joku kundi sano mulle et 'ai jaa hän mietti sitä aikoinaan', mä vähä tilanteen mukaan tunnustelin et mikä filis oli”

Vanhan ja uuden ammatillisen identiteetin välimaastossa, liminaalissa, ollessaan ihminen ei itsekään oikein tiedä, mihin itsensä ruumiillisesti asemoisi. Ulospäin suuntautunutkin voi vetäytyä ammatillisen identiteettinsä osalta piiloon suojatakseen itseään: jotain, mitä ei vielä itse näe, ei kannata muillekaan näyttää. Tunnusteleminen on alanvaihtajan keino tehdä identiteettityötä omassa tahdissa. Yhtäältä se on itsen suojaamista, toisaalta uuden raivaamista sopivien tilanteiden tullen.

Tunnustelemista on myös omien syvien, koko ihmiselämää ja sen tarkoitusta koskevien olettamusten tarkasteleminen. Birgitta kuvailee itselleen tekemää synninpäästöä:

"siis itse mietin et oonks mä jotenki niinku huono ihminen kun mä nyt lähden vaan tätä omaa . haluani toteuttamaan miettimättä sitä et miten . tai mietin kyllä mut jotenki mä oon hirveen ankara ollu itelleni siinä ja oon yhäti . mut sit on niinku pakko . antaa itelleen anteeks . et okei et tää nyt menee näin”

Birgitta käyttää voimakkaita sanoja: hän puhuu huonosta ihmisestä, pelkästään oman halun toteuttamisesta ja itselleen anteeksi antamisesta, vaikka tosiasiassa hän oli miettinyt ja suunnitellut perheen taloudellisia asioita hyvinkin paljon. Birgitta reflektoi pohtimalla, kuinka ankara hän on ollut itselleen. Jotkin teot näyttäytyvät vuorotellen hyvän ihmisen ja huonon ihmisen toimintana sen mukaan, katsoiko niitä uudesta vai vanhasta asemoitumisesta käsin. Kun työruumis asettuu uuteen asentoon, sen on hyväksyttävä tietynlainen epärationaalisuus ja suunnittelemattomuus, joka kuuluu alanvaihtajan ammatilliseen kasvuun.

\section{TULOLLAAN OLEMINEN}

Vaikka haastateltavat kokivat urasiirtymässään monenlaisia ristiriitoja, epävarmuutta ja vaikeutta, esiin piirtyvä kertomus korkeakoulutetun alanvaihdosta on myönteinen. Anna, Birgitta ja Cecilia löysivät etsimänsä ja saivat rauhan itsensä kanssa. Ei ole itsestään selvää, että aikuinen liminaalitilan ja ikään kuin identiteetittömässä tilassa vietetyn ajan jälkeen löytää tulollaan olevan uuden ammatillisen identiteetin. Tutkimuksessani ihmisruumis kuitenkin näyttäytyy itseään korjaavana mekanismina: sillä on kyky koota palaset ja eheytyä, pyrkiä ja päsäsä sopusointuun vaikeistakin ristiriidoista ja kurottaa kohti uutta. 
Alanvaihtaja KantaA

RUUMIISSAAN ARVOJA JA

KULTTUURIA, JOIHIN ON

AIEMMIN SITOUTUNUT.

Alanvaihto on tulemista johonkin aivan konkreettisesti, kun työruumis etsii uuden paikan, jonne lähteä aamuisin. 'Tulemisella' viittaan kuitenkin ennen kaikkea uuteen identiteettiin kasvamiseen. Suomen kielessä ei ole yhtä sanaa, joka vastaisi englannin kielen sanaa becoming mutta sen voi suomentaa 'tulollaan olemiseksi'. Tulollaan olemisella on yhteys liikkeeseen, erilaisuuteen, ainutkertaisuuteen sekä kielen ja materiaalisuuden yhteen kietoutumisiin. (Salo 2015, 178.) Siinä on prosessuaalisia piirteitä, mutta se ei tyhjenny prosessiin eikä sillä ole selvää päämäärää, vaan se on dynaamisessa liikkeessä, tulossa joksikin, kuten Birgitta kuvailee:

"se vaan antaa niin paljon . et mä oon siinä niinkun uus ihminen ja löytäny niinku ittestäni semmosii puolii mitä mä en olis kakskymppisenä voinu ikinä uskoo . et mä en olis sillon voinu ruveta opettajaksi et mä oon niinku kasvanu . ihmisenä . tähän opettajuuteen jotenki niinku itsessäni”

Liminaalitilassa on mahdollisuus muutokseen ja uuden luomiseen, sillä ihminen on irrallaan työelämän säännöistä ja rutiineista ja eri ammatillisten roolien sosiaalisista normeista. Miltä tulollaan oleminen sitten tuntuu? Liminaalitila on yhdistetty psykologi Mihaly Csikszentmihalyin (1990) käsitteeseen virtauksesta eli flow'sta, kokonaisvaltaisesta ja totaalisesta keskittymisestä (Kontinen 2013, 255).

Vaikka Cecilialla oli taustalla rankkoja kokemuksia myymäläpäällikön työn kariutumisesta ja lapsensa sairaudesta, hän onnistui löytämään liminaalitilassaan erityispedagogiikasta flow'n. Tuntemuksensa turvin hän alkoi uskoa alanvaihdon toteutumiseen. ”ehkä se jotenki et kun mä löysin sen oman jutun . sen Alisan diagnoosin myötä jotenki et se erityispedagogiikka meni niinku niin helposti se oli niin kiinnostavaa ni siin kohtaa mä aloin uskomaan et täst tulee niinku jotain . ja et tää vie mut niinku johonki ja et nyt mä löysin sen mun jutun mitä mä oikeest haluaisin tehdä niinku joka päivä”

Cecilia oli aiemminkin opiskellut kasvatustiedettä avoimessa yliopistossa, mutta vasta flow-tuntemusten myötä, kun opinnot sujuivat helpon tuntuisesti, hän vakuuttui löytäneensä oman juttunsa. Oman jutun löytäminen ei ole hetkellinen hyvän olon tuntemus, vaan se suuntautuu tulevaisuuteen. Cecilia käyttää identiteettityössään mielikuvitustaan pohtiessaan, että erityispedagogiikka olisi jotain sellaista, mitä hän tekisi mielellään - ei pelkästään tänään vaan joka päivä tulevaisuudessakin.

Tulollaan olemisen tilassa ei ole enää toiseuden tunnetta. Ihminen on kuin kala vedessä, kuten Birgitta kuvailee:

"mul on semmonen et mä oon oikees paikas ja mä oon tekemäs just sitä mitä mun kuuluu nyt tehdä ja et se antaa niinku ihan hirveesti energiaa ja se vapauttaa myös sitä semmosta tota vaik tekemistä on paljo"

Koska ammatillinen identiteetti perustuu ihmisen elämänhistoriaan, varsinkin aikuisopiskelijoilla sitä muokkaa myös ennen yliopisto-opintoja hankittu työkokemus (Nori \& Mäkinen-Streng 2017). Alanvaihtaja tulee jostakin ja kantaa ruumiissaan aina jotakin niistä arvoista ja kulttuurista, joihin oli aiemmin sitoutunut. Vaikka siteet ovat löystyneet ja osittain irronneet, ruumis pitää niistä kiinni, oppii ja oppii pois niiden avulla.

Joksikin tuleminen on ennalta arvaamatonta, ulkopuolisen näkökulmasta hulluakin: ihminen niin sanotusti vapaaehtoisesti jättää taakseen hyvät olot aloittaakseen jotain uutta, esimerkiksi sanoutumalla irti vakituisesta työpaikasta. Liitän ennustamattomuuden ajatukseen ruumiin rehellisyydestä. Kehittymistä janoavan ihmisen (Boyatzis \& Kolb 2000, 85-86) elämä ei mene aivan niin kuin hän on suunnitellut, mutta ehkä sen ei kuulu mennäkään, kuten 


\section{RUUMiIN ON OTETTAVA}

\section{KANTAA, VALITTAVA REITIT}

\section{JA RUTIINIT.}

Massumin $(2002,18)$ ajatus osoittaa: "Jos aloittaessaan tietää, mihin tulee lopettamaan, mitään ei tapahdu alun ja lopun välillä.”

Anna ja Birgitta opiskelivat luokanopettajan koulutusohjelmassa, ja Cecilia pääaine oli erityispedagogiikka. Jonkin vähemmän selkeän ammattiidentiteetin etsiminen saa varmasti aikaan erilaisia tuntemuksia. Vaikka haastateltavat kouluttautuivat selkeään ammattiin, heidän alanvaihtoonsa liittyvät tuntemukset olivat monimutkaisia ja heille itselleenkin yllättäviä. Opettajuus ei ollut haastateltavilla kirkkaana mielessä, vaan tulollaan olemisen tilassakin haastateltavat rakensivat uutta kuvaa ammatillisesta identiteetistään pienistä palasista, kuten aiemmasta työkokemuksestaan, valitsemistaan sivuaineista, sijaisuuksista ja harjoitteluista, tutkimustaitojen opinnoista ja perhe-elämän asettamista raameista.

\section{ALANVAIHDON TUNNESÄVYT}

Jokisen ja tutkijakumppaneidensa $(2015,25)$ mukaan tuntemuksia ei voida lähestyä puhtaan empiristisesti, löytöretkeilemällä, vaan ne on pikemminkin keksittävä. Ruumiillisuus- tai affektitutkimuksen tehtävänä ei ole vain kuvata jo havaittavissa olevaa vaan myös luoda uusia tapoja jäsentää maailmaa ja löytää yksilöllisten kokemusten ja tunnesävyjen kautta keinoja, joilla on mahdollista tehdä elämästä siedettävää epävarmuuden keskellä (Jokinen ym. 2015, 25).

Artikkelissani olen nimennyt alanvaihdon tunnesävyjä affektiivisiksi tiloiksi. Irtoamisen tilassa ihminen irtoaa aiemmasta ammatillisesta identiteetistään. Puhdistumisen tilassa identiteetti on ikään kuin pesussa. Se ei ole enää vanhaa vaan valmistautuu uuteen, ja tämä tuntuu yhtäältä epämääräiseltä mutta toisaalta toiveikkaalta. Tulollaan olemisen tilassa uusi ammatillinen identiteetti muodostuu ja kasvaa uudelle perustalle. Tunnusteleminen liittyy kaikkiin alanvaihdon tiloihin, ja ajattelen sen olevan ruumiillista reflektointia.

Työelämä tempaisee mukaansa ja ulottuu ihmisen henkilökohtaisimmille alueille. Sosiaalisten normien ja henkilökohtaisten tuntemusten välinen punninta ei ole helppoa (Haynes 2008; 2012), minkä vuoksi alanvaihdon identiteettityö voi viedä vuosikausia ja tuntua raskaalta: sitä haluaa mukautua mutta samalla olla autenttinen.

Ruumiillisuutta voi ajatella muutoksen ja muutoksen vastustuksen kohtaamispaikkana (Jokinen ym. 2004, 10). Kohtaamiset voivat olla rajuja, tai sitten uusi ammatillinen identiteetti kehittyy hiljalleen kypsytellen, kunnes ruumis irtoaa vanhasta kuin kypsä hedelmä puusta. Tällainenkaan kohtaaminen ei ole ristiriidaton, vaan siihen voi sisältyä suurtakin pettymystä ja syyllisyyttä.

Muutokseen vievät ja muutosta vastustavat voimat voivat myös käydä armottomia kamppailuja ihmisruumiissa. Mitä pukea ylle uusiin työtehtäviin mennessä? Miten pukea sanoiksi tapahtunutta muutosta ja vanhaa identiteettiä uudesta, vielä hauraasta identiteetistä käsin? Ristiriidat hämmentävät. Viime kädessä muutos ja muutoksen vastustus kuitenkin kohtaavat, sillä ruumiin on otettava kantaa, valittava reitit ja rutiinit.

Mitä vanhasta identiteetistä jää jäljelle alanvaihdon myötä, kun ihminen on luonut nahkansa? Taiteen tutkija Riikka Mäkikoskelan (2007) mukaan ihminen voi helposti omaksua uusia ajatuksia, mutta ruumiillisuus paljastaa todelliset luutuneet asenteet, joiden muuttaminen vaatii aikaa. Ruumiillinen olemus ja toiminta kertovat toisille, mitä ihminen on oppinut elämästä ja miten hän on sisäistänyt oppimansa (Mäkikoskela 2007).

Olen tuonut esille, millaisten tuntemusten kautta alanvaihtaja tekee identiteettityötään. Ammatillista kehittymistä ei haeta pelkästään oppilaitoksen tai työpaikan seinien sisältä, vaan alanvaihto on monimutkainen kasvun prosessi, jossa askeleita otetaan välillä kaksi eteen ja yksi taakse. Alanvaihtaja kantaa loppuelämänsä mukanaan irtoamista sekä jotain siitä, mistä on irronnut ja mitä on alkanut katsoa toisin. Tilan tekeminen, puhdistuminen ja välissä oleminen 
jättävät jälkensä alanvaihtajan ruumiiseen. Ruumis osaa kuitenkin myös kiinnittyä merkityksellisen tuntuiseen alaan uutta perusta luovalla tavalla.

Millaisia toimijuuden paikkoja (Filander \& Siivonen 2018) on tarjolla keski-ikää lähestyvien, jo työuralla olevien naisten pyrkimyksille vaihtaa alaa ja pohjimmiltaan koko identiteettiä? Millaiset ihmiset asettuvat aikuiskasvatettaviksi (Filander \& Siivonen 2018)? Vaikka mahdollisuuksia valkoihoiselle ja keskiluokkaiselle suomalaisnaiselle toki on, on syytä varoa liiallista optimismia omaehtoisen uudelleenkouluttautumisen suhteen.

Aineistoni perusteella sekä ihmisten omat että sosiaaliset odotukset ovat edelleen urautuneita, eikä "itsen vaihtaminen" käy käden käänteessä. Haastateltavieni tuntemuksia leimasivat epävarmuus ja epäusko. Toimivan väylän alanvaihdolle tarjosi harrastusluonteisuus. Avoimessa yliopistossa ja pieninä opintokokonaisuuksina uutta identiteettiä pystyi edistämään vaivihkaa. Työssä käyvä perheellinen saattaa tavoitella alanvaihtoa ja uutta identiteettiä. Tavoitteiden naamioinen harrastukseksi luo suojaa toimijuudelle.

Epävarmoihin olosuhteisiin perustuvassa työelämässä on mahdollisuus yllättäviin muutoksiin. Alanvaihtajan identiteettityö näyttäytyy artikkelissani melko raskaana ja yksinäisenä, kun uutta identiteettiä pitää tarkoin varjella. Kuitenkin on toiveikasta, miten ihmisruumis pystyy luomaan jotain uutta, selkeästi aikaisemmasta poikkeavaa. Työelämän subjektivoituminen ja henkilökohtaistuminen ovat vaarallisia ilmiöitä, jos niitä ei tiedosteta. Haastateltavani kuitenkin näyttivät pystyvän aidosti löytämään itseään uuden koulutuksen ja työn avulla ja rikkomaan sosiaalisten normien luomia kahleita.

Kuten sukupuoliteoreetikko Elizabeth Grosz (1994) toteaa, ruumis toimii vuorovaikutuksessa ja tuottavasti: se toimii ja reagoi, ja saa aikaan uutta, yllättävää ja ennustamatonta. Aikuiskasvatuksessa tarvitaan lisää monitieteistä tutkimusta siitä, miten ruumis - jota voisi myös kutsua yllätysmomentiksi - toimii ja käyttäytyy, ja mikä ruumiillisuuden rooli on aikuisen ammatillisuudessa. Ilman ruumiillisuuden huomioimista monet yritykset ymmärtää aikuisen kasvua ja oppimista jäävät vaillinaisiksi, sillä ne eivät tavoita ihmistä kokonaisena toimijana ja Mäkikoskelan (2007) sanoin "kokonaisvaltaisena maailmassaolijana".

Ruumiillisuuden näkökulma tuo esiin, kuinka aikuisen alanvaihtoon sisältyy myös yllätyksellisyyttä ja ennustamattomuutta. Liminaalisuuden ajatusta identiteettien välimaastossa olemisena on viety eteenpäin organisaatiotutkimuksessa (Beech 2011). Artikkelini on yksi avaus sen pohdinnalle, miten liminaalisuus ilmenee aikuisen uudelleenkouluttautumisessa.

Monen ammattikunnan edustajat kohtaavat työssään alanvaihtajia: opettajat ja opinto-ohjaajat oppilaitoksissa, esimiehet ja henkilöstöasiantuntijat työorganisaatioissa sekä uraohjaajat työvoimapalveluissa ja yksityisellä sektorilla. Välitilassa olevalla ihmisellä saattaa olla meneillään hyvinkin intensiivinen identiteetin rakentamisen vaihe. Silloin hän ei halua pelkästään mekaanisesti omaksua uutta tietoa koulutuksessa tai työelämässä, vaan hänen koko ruumiinsa tunnustelee ympäristöä ja sovittaa yhteen vanhoja ja uusia identiteetin palasia. Niinpä koulutuksessa ja työelämässä on tärkeää tunnistaa, tehdä näkyväksi ja tukea identiteettityötä, kuitenkin pitäen mielessä, että kyse on hyvin henkilökohtaisesta asiasta.

Vaikka aikuisena kouluttautumisesta on tullut uusi normaali (Silvennoinen \& Lindberg 2015, 268), aikuisena kuljetut opintopolut eivät ole suoraviivaisia, vaan ne kiinnittyvät kouluttautujan aiempaan ammatilliseen ja ruumilliseen identiteettin. Jos halutaan ymmärtää alanvaihtajan tuntemuksia, on syytä kysyä: Mistä ihminen haluaa tai on pakotettu irtoamaan? Miten hän puhdistuu ja oppii pois vanhasta? Entä miten uuden, tulollaan olevan löytäminen tapahtuu ja kuinka sitä vaalitaan? Jokainen alanvaihto on ruumiillinen, sillä ihminen elää ja oppii ruumiina.

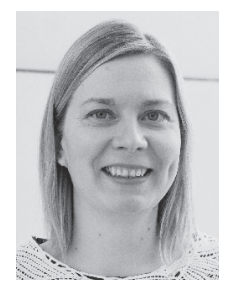

\section{MIRVA HEIKKILÄ}

KM, OTM, projektipäällikkö, tohtorikoulutettava opettajankoulutuslaitos kasvatustieteiden tiedekunta Turun yliopisto 


\section{Litterointimerkit}

$\begin{array}{ll}/ / \mathrm{mmm} / / & \text { tauko } \\ \frac{\text { ei }}{\text { la- }} & \text { kirjoittajan puhetta } \\ \text { (naurua) } & \text { alleviivattu äänne, sana tai lauseenosa sanottu painokkaasti } \\ \text { [työnantaja] } & \text { ei-verbaali toiminto } \\ & \text { kirjoittajan kommentti }\end{array}$

\section{LÄHTEET}

Alsup, J. (2006). Teacher Identity Discourses. Negotiating Personal and Professional Spaces. Mahwah, NJ: Lawrence Erlbaum.

Aromaa, J. (2014). Ruumiillinen tieto opettajan työssä. Teoksessa Brunila, K. \& Isopahkala-Bouret, U. (toim.) Marginaalin voima! Aikuiskasvatuksen 51. vuosikirja. Helsinki: Kansanvalistusseura ja Aikuiskasvatuksen Tutkimusseura, 194-221.

Beech, N. (2011). Liminality and the practices of identity reconstruction. Human Relations 64(2), 285-302.

Beauchamp, C. \& Thomas, L. (2009). Understanding teacher identity: an overview of issues in the literature and implications for teacher education. Cambridge Journal of Education 39(2), 175-189.

Boyatzis, R. E.\& Kolb, D. A. (2000). Performance, learning, and development as modes of growth and adaptation throughout our lives and careers. Teoksessa Peiperl, M. Arthur, M., Goffee, R. \& Morris, T. (eds.) Career Frontiers. New Conceptions of Working Lives. New York: Oxford University Press, 76-98.

Brunila, K. Onnismaa, J. \& Pasanen. H. (2015). Johdanto. Teoksessa Brunila, K., Onnismaa, J., \& Pasanen, H. (toim.) Koko elämä töihin. Koulutus tietokykykapitalismissa. Tampere: Vastapaino, 9-24.

Csikszentmihalyi, M. (1990). Flow: The Psychology of Optimal Experience. New York: Harper and Row.

Ekonen, M. (2007). Moninaiset urat - Narratiivinen tutkimus naisjohtajien urakehityksestä. N:o 170/2007. Lisensiaatintutkimus. Jyväskylän yliopisto.

Estola, E. \& Elbaz-Luwisch, F. (2010). Teaching bodies at work. Journal of Curriculum Studies 35(6), 697-719.

Estola, E., Uitto, M. \& Syrjälä, L. (2017). Elämänkertahaastattelu. Teoksessa Hyvärinen, M., Nikander, P. \& Ruusuvuori, P. (toim.) Tutkimushaastattelun käsikirja. Tampere: Vastapaino, 153-173.

Eteläpelto, A. \& Vähäsantanen, K. (2010). Ammatillinen identiteetti persoonallisena ja sosiaalisena konstruktiona. Teoksessa Eteläpelto, A. \& Onnismaa, J. (toim.) Ammatillisuus ja ammatillinen kasvu. Aikuiskasvatuksen 46. vuosikirja. Kansanvalistusseura ja Aikuiskasvatuksen Tutkimusseura, 26-49.
Filander, K. (2006). Työ, koulutus ja katoavat ammattiidentiteetit. Teoksessa Mäkinen, J., Olkinuora, E., Rinne, R. \& Suikkanen, A. (toim.) Elinkautisesta työstä elinikäiseen oppimiseen. Jyväskylä: PS-Kustannus, 43-60.

Filander, K. \& Siivonen, P. (2018). Koulutus hallinnassa - entä aikuiskasvatus? Teoksessa Jauhiainen, A., Kivirauma, J. \& Kinnari, H. (toim.) Koulutus hallinnassa. Turun yliopiston kasvatustieteiden tiedekunta julkaisusarja A:216, 473-501.

Gordon, T., Holland, J. \& Lahelma, E. (2000). Moving bodies/still bodies. Embodiment and agency in schools. Teoksessa McKie, L. \& Watson, N. (eds.) Organizing Bodies. Policy, Institutions and Work. Houndmills: Macmillan Press, 81-101.

Grosz, E. (1994). Volatile bodies. Toward a Corporeal Feminism. Bloomington: Indiana University Press.

Haynes, K. (2008.) (Re)figuring accounting and maternal bodies: the gendered embodiment of accounting professionals. Accounting, Organizations and Society 33(4-5), 328-348.

Haynes, K. (2012.) Body beautiful? Gender, identity and the body in professional service firms. Gender, Work and Organization 19(5), 490-507.

Huopalainen, A. \& Satama, S. (2018). Mothers and researchers in the making: Negotiating 'new' motherhood within the 'new' academia. Human Relations. http://journals.sagepub.com/doi/ full/10.1177/0018726718764571 (19.6.2018.)

Hyvärinen, M. (2010). Haastattelukertomuksen analyysi. Teoksessa Ruusuvuori, J., Nikander, P. \& Hyvärinen, M. (toim.) Haastattelun analyysi. Tampere: Vastapaino, 90-118.

Hänninen, V. (2002). Sisäinen tarina, elämä ja muutos. Akateeminen väitöskirja. Tampereen yliopistopaino Oy Juvenes Print.

Högbacka, R. \& Aaltonen, S. (2015). Refleksiivisyyden ulottuvuudet. Teoksessa Aaltonen, S. \& Högbacka, R. (toim.) Umpikujasta oivallukseen. Refleksiivisyys empiirisessä tutkimuksessa. Nuorisotutkimusverkosto/ Nuorisotutkimusseura, julkaisuja: 164. Tampere: Tampere University Press, 9-31. 
Ibarra, H. (1999). Provisional selves: experimenting with image and identity in professional adaptation. Administrative Science Quarterly 44(4), 764-791.

Ibarra, H. (2004). Working Identity: Unconventional Strategies for Reinventing Your Career. Boston, MA: Harward Business School Press.

Izadinia, M. (2013). A review of research on student teachers' professional identity. British Educational Research Journal 39(4), 649-713.

Johansson, J., Tienari, J. \& Valtonen, A. (2017). The body, identity and gender in managerial athleticism. Human Relations 70(9), 1 141-1 167

Jokinen, E., Kaskisaari, M. \& Husso, M. (2004). Ruumiin taju. Rakenteet, kokemukset, subjekti. Teoksessa Jokinen, E., Kaskisaari, M. \& Husso, M. (toim.) Ruumis töihin! Käsite ja käytäntö. Tampere: Vastapaino, 7-13.

Jokinen E., Venäläinen, J.\& Vähämäki, J. (2015). Johdatus prekaarien affektien tutkimukseen. Teoksessa E. Jokinen \& J. Venäläinen (toim.) Prekarisaatio ja affekti. Nykykulttuurin tutkimuskeskuksen julkaisuja 118. Jyväskylän yliopisto 2015, 7-30.

Julkunen, R. (2008). Uuden työn paradoksit. Tampere: Vastapaino.

Juvonen, T. (2017). Sisäpiirihaastattelu. Teoksessa Hyvärinen, M., Nikander, P. \& Ruusuvuori, J. (toim.) Tutkimushaastattelun käsikirja. Tampere: Vastapaino, 398-410.

Kamila, M. (2012). Katsojana ja katsottuna: Opettajan kontrolloitu ulkoasu. Jyväskylä: Nykykulttuurin tutkimuskeskuksen julkaisuja 110.

Khapova, S., Arthur, M., Wilderom, C. \& Svensson, J. (2007). Professional identity as the key to career change intention. Career Development International 12(7), 584-595.

Kinnunen, T. \& Seppänen, J. (2012). Oikeaoppinen opettajaruumis. Naistutkimus 22(4), 6-17.

Koivunen, A. (2010). An affective turn? Reimaging the subject of feminist theory. Teoksessa Liljeström, M. \& Paasonen, S. (toim.) Working with Affect in Feminist Readings: Sisturbing Differences. London: Routledge, 8-27.

Koivunen, M., Lämsä, A.-M. \& Heikkinen, S. (2012). Urasiirtymät muuttuvassa työelämässä - Analyysi urasiirtymän käsitteestä. Jyväskylän yliopiston kauppakorkeakoulun Working paper N:o 371/2012. https:// www.jyu.fi/jsbe/tutkimus/julkaisut/workingpaper/ wp371(Luettu 14.12.2016.)

Kolehmainen, M. (2014). Affektiteoriaa yhteiskuntatieteilijöille. Sosiologia 51(2), 184-186.

Kontinen, T., Houni, P., Karsten, H. \& Toivanen H. (2013). Liminaalitilan käsite työn muutosten jäsentäjänä. $A i-$ kuiskasvatus 33(4), 252-264.

Laakkonen, E. (2015). Aikuisuuden kulttuuriset kuvat 25-35-vuotiaiden naisten haastattelupuheissa ja naistenlehtiteksteissä. Publications of the University of Eastern Finland. Dissertations in Education, Humanities and Theology, no 69.
Lahikainen, L. \& Harni, E. (2016). Yrittäjämäinen ruumis palvelutaloudessa. Teoksessa Parviainen, J., Kinnunen, T. \& Kortelainen, I. (toim.) Ruumiillisuus ja työelämä. Työruumis jälkiteollisessa taloudessa. Tampere: Vastapaino, 26-39.

LaPointe, K. (2011). Moral struggles, subtle shifts. Narrative practices of identity work in career transitions. Aalto University publication series. Doctoral Dissertations 34/2011.

LaPointe, K. \& Heilmann, P. (2014). 'Daring leaps'. Construction of meaning and individual agency in career change narratives in media. Nordic Journal of Working Life Studies 4(2), 47-64.

Laulainen, S. \& Hujala, A. (2016). Material construction of care workers' identity. Nordic Journal of Working Life Studies 6 (Supplement 1), 7-25.

Leivo, M. (2010). Aikuisena opettajaksi. Aikuisopiskelijoiden merkittävät oppimiskokemukset opettajan työn ja opettajankoulutuksen vuorovaikutuksessa. Akateeminen väitöskirja. Kokkola: Jyväskylän yliopisto, Kokkolan yliopistokeskus Chydenius.

Louis, M. R. (1980). Career transitions: Varieties and commonalities. The Academy of Management Review 5(3), 329-340.

Mannevuo, M. (2015). Affektitehdas. Työn rationalisoinnin historiallisia jatkumoita. Akateeminen väitöskirja. Turun yliopiston julkaisuja - Annales universitatis turkuensis. Sarja C, osa 406. Turku: Scripta Lingua Fennica Edita.

Merleau-Ponty, M. (2012). Maurice Merleau-Pontyn julkaisematon kirjoitus - Filosofin katsaus tuotantoonsa. (suom. M. Luoto) Teoksessa Luoto, M. \& Roinila, T. (toim.) Maurice Merleau-Ponty - Filosofisia kirjoituksia. Keuruu: Otavan Kirjapaino Oy, 59-111.

Mäkikoskela, R. (2007). Kokonaisvaltaisen maailmassaolijan vuorovaikutuksellinen kasvaminen ja oppiminen. Aikuiskasvatus 27(4), 312-319.

Massumi, B. (2002). Parables for the Virtual: Movement, Affect, Sensation. Durham \& London: Duke University Press.

Nikkola, T. \& Harni, E. (2015). Sisäistyneet ristiriidat, tunnetyö ja tietotyöläissubjektiviteetin rakentuminen. Aikuiskasvatus 35(4), 244-253.

Nori, H. \& Mäkinen-Streng, M. (2017). Koulutukseen valikoituminen, kiinnittyminen ja sosialisaatio. Teoksessa Murtonen M. (toim.) Opettajana yliopistolla. Korkeakoulupedagogiikan perusteet. Tampere: Vastapaino, 318-347.

Onnismaa, J. \& Pasanen, H. (2015). Identiteetit markkinoilla. Teoksessa Brunila, K., Onnismaa, J. \& Pasanen, H. (toim.) Koko elämä töihin. Koulutus tietokykykapitalismissa. Tampere: Vastapaino, 245-281.

Parviainen, J., Kinnunen, T. \& Kortelainen, I. (2016). Johdatus työruumiin tutkimukseen. Teoksessa Parviainen, J., Kinnunen, T. \& Kortelainen, I. (toim.) Ruumiillisuus ja työelämä. Työruumis jälkiteollisessa taloudessa. Tampere: Vastapaino, 9-25. 
Rikala, S. (2013). Työssä uupuvat naiset ja masennus. Akateeminen väitöskirja. Acta Universitatis Tamperensis 1854. Tampere: Tampereen yliopistopaino.

Räsänen, K. \& Trux, M.-L. (2012). Työkirja. Ammattilaisen paluu. Helsinki: Kansanvalistusseura.

Saari, A. (2016). Tietoisuustaitojen ristiriidat opetustyössä. Teoksessa Parviainen, J., Kinnunen, T. \& Kortelainen, I. (toim.) Ruumiillisuus ja työelämä. Työruumis jälkiteollisessa taloudessa. Tampere: Vastapaino, 199-214.

Salmela, M. (2017). Affektiivinen käänne. Tieteessä tapahtuu 35(2). https://journal.fi/tt/article/view/61405/23049 (25.2.2018).

Salo, U.-M. (2015). Simsalabim ja sisällönanalyysi. Teoksessa Aaltonen, S. \& Högbacka, S. (toim.) Umpikujasta oivallukseen. Refleksiivisyys empiirisessä tutkimuksessa. Nuorisotutkimusverkosto/Nuorisotutkimusseura, julkaisuja: 164. Tampere: Tampere University Press, 166-190.

Satama, S. (2017). Capturing movement that evades the eye: A sensory ethnography of the 'hidden' qualities of embodied agency in professional dance. Akateeminen väitöskirja. Turun yliopiston julkaisuja - Annales Universitatis Turkuensis E 16.

Silvennoinen, H. \& Lindberg, M. (2015). Aikuiskoulutukseen osallistuminen Suomessa. Aikuiskasvatus 35(4), 266-285.

Sitra. (2017). Työelämätutkimus. https:// media.sitra.fi/2017/05/16144238/ SitraTy\%C3\%B6el\%C3\%A4m\%C3\%A4n-tutkimus2017-FINAL_sitrafi_PDF.pdf (21.7.2017).
Strati, A. \& deMontoux, P. G. (2002). Introduction: organizing aesthetics. Human Relations 55(7), 755-766.

Tannen, D. (1993). What's in a frame? Surface evidence for underlying expectations. Teoksessa D. Tannen (toim.) Framing in Discourse. Oxford: Oxford University Press, 14-56.

Vachhani, S. J. (2006). The death of a salesman? An exploration into the discursive production of sales identities. Culture and Organization 12(3), 249-264.

Vahtera, S. (2017). Uusiin saappaisiin. "Ennen ja jälkeen" uuden ammatin ja uran. Tutkimusraportti. https://www.sak.fi/aineistot/julkaisut/mahdollisuuksien-aika/uusiin-saappaisiin--ennen-ja-jalkeen-uudenammatin-2017-06-27 (10.11.2017).

Valkonen, J. \& Valkonen, S. (2014). Uskottavat safariruumiit: sukupuoli ja ruumiillisuus palvelutuotetaitoina Lapin safariturismissa. Työelämän tutkimus 12(3), 244-256.

Virno, P. (2006). Väen kielioppi: ehdotus analyysiksi nykypäivän elämänmuodoista. Helsinki: Tutkijaliitto.

Wetherell, M. (2012). Affect and Emotion. A New Social Science Understanding. London: SAGE.

Wolkowitz, C. (2006). Bodies at Work. London: SAGE.

Ylitapio-Mäntylä, O. (2016). Opiskelijoiden näkemyksiä lastentarhanopettajan työstä uuden työn kulttuurissa. Aikuiskasvatus 36(4), 258-269. 